\title{
Requirements for the Success of the Integration Program of Disabled Students in the Regular Schools from the Perspective of the Teachers of the Learning Resources Rooms
}

\author{
Jihad At-Turki \\ Tafilah Technical University, Faculty of Educational Sciences \\ Educational Psychology Section \\ Hisham Ali ALdmour \\ Dean of the Al Karak University College \\ E-mail: saifdhmour@yahoo.com \\ Khalil A.R Al Maitah \\ Al-Balqa Applied University, Jordan \\ Mohammad Nayef ALsarayreh (Corresponding author) \\ Educational and Social Sciences Department \\ AlBalqa Applied University, Jordan, Karak
}

Tel: 96-277-719-8864 E-mail: mohammad_n_k_s@yahoo.com

$\begin{array}{lc}\text { Received: July 4, } 2011 \quad \text { Accepted: July 26, } 2011 \quad \text { Published: February 1, } 2012 \\ \text { doi:10.5539/ies.v5n1p108 } & \text { URL: http://dx.doi.org/10.5539/ies.v5n1p108 }\end{array}$

\begin{abstract}
The purpose of this study is to identify the requirements for the success of the integration program and to find out the causes of success and to provide optimal services for the students with disabilities in regular schools. The study attempts to answer the following questions:

1. What are the most important requirements of the success of the integration of disabled persons in regular schools from the viewpoint of the teachers of the learning resources rooms

2. Are there any statistically significant differences to the level of ( $\alpha(0.05 \geq$ in the requirements of disabilities program success of integration in regular schools from the teachers of learning resources rooms- perspectives attributed to the variable of gender?

3. Are there any statistically significant differences to the level of ( $\alpha(0.05 \geq$ in the requirements of disabilities program success of integration in regular schools from the teachers of learning resources rooms- perspectives attributed to the variable the years of experience?

4. What is the most appropriate educational option for students with disabilities (The academic integration, social integration, classes attached to the regular school, general education class with their peers, the integration program of the full-day, partial day program integration, from the viewpoint of the teachers of the learning resources rooms)?

The study sample consisted of (140) male and female teachers in the learning resources rooms in public and private schools in the Directorate of Amman. These were selected in a simple random manner. And a list of assessment was used to collect information consisting of 70 items, distributed on seven axes (teachers and administration, school environment, supporting services, awareness, students with disabilities, the type of the program which is the most important from the viewpoint of the teachers of the learning resources rooms). The stability and reliability of the instrument were verified using the test and re-test method.
\end{abstract}

The results indicate that the requirements of the success of the integration program, appeared in descending order, were as follows: awareness, support services, integration programs, the domain of the school environment, teachers, 
students with disabilities, The results also indicate that the program that is the most important and appropriate for students were arranged as follows: the program of social integration, the academic integration program, the program of the integrated public class, program of partial integration, program of private class attached to the regular school, the long- term integration program (Full-day).

Keywords: School, Disabled students, Teacher

\section{Introduction}

The concept of integration appeared in the late twentieth century as a term and modern philosophy of Special Education, which puts a status for the disabled child and makes him feel himself, and his being, and increases his sense of belonging to society and that he is not a stranger to it. That he has rights which he must enjoy, such as the right to equality in education, work, and other services And he has duties that he must perform as a member of the community And through the slogan put forward by the United Nations, that is the right of education and work for people with disabilities led to the moving of most countries in the world to implement integration programs for students with disabilities in all their categories in regular schools with their peers without disabilities, and therefore integration included work as well as increasing the sense of the disabled individual of himself and thus, we helped the individual to adapt interaction with his community and that he is an active member of this community (Sayari, 2009)

The integration of people with disabilities in the community is considered one of the advanced steps that the various rehabilitation programs consider it a key target for the rehabilitation of people with disabilities recently. The concept of integration, in its essence is a social and moral concept stems from the human rights movement against classification and segregation of any individual because of his disability. The policy of integration is the educational practice of the general principle that guides special education services, and it is the normalization toward the ordinary in the environments with the least restrictions. Some researchers, the supporters of this philosophy, believe that the integration provides the opportunity for interaction of the disabled with their peers who are without disabilities and learning from them, and qualifies him to working and dealing with others in an environment closer to the big community and more representative of it. It assists the growth of the academic and social sides for children, but for the community, in addition to being consistent and compatible with the moral values of society and culture, it reinforces the growth of society and its consciousness to understand and appreciate the individual differences between people, and provides the opportunity to produce private services.

\section{Previous Studies}

The report, in which (Zakaria, 1995) described six Jordanian schools which applied integration in terms of the administrative and applied aspects for those programs, pointed to a number of important points in its conclusions; and which was represented in the general agreement between the six schools that the regular school is the best environment suites the accommodation of children with special needs. The enrollment of children, in regular classes, for some time with the provision of support services in special classes for other periods may be the perfect alternative in the environment of integration. Most of the schools had agreed on a number of drawbacks or difficulties that face the integration programs, which emerged in the lack of trained personnel to work with integrated children, and many of the officials resort to the personal interpretations with respect to the programs that are presented for assimilated children, and the preparation of training programs for teachers. And it seems that the negative trends of some teachers of regular classes toward children with disabilities limited their acceptance of integrated students. In addition to the negative trends of the families of ordinary children, in those schools, and the large number of complaints and annoyance from non-ordinary peers, formed a real obstacle to the establishment of a positive social interaction within the school, which resulted in the presence of integrated children, in a normal school, who suffer from isolation and lack of appropriate services.

The study that is carried out by Cook and his colleagues (Cook, Bryan, Semmel, Melvyn, and Gerrer, 1991) indicates the contentment of the administrators of some regular schools that applied the integration in the U.S., with the positive benefits left by the integration on the achievement of the children with mild disabilities, and on the other aspects when they get greater access to support services during the integration. Teachers of the special education in those schools also stressed the integrated children's need to get supporting learning tools regardless of the educational alternative from which they learn. And it seems that the positive trends for each of the managers and teachers in those schools were a catalyst for many developments for those children.

And in the study of (Assartawi, Zidane, Assartawi, Abdul Aziz, Jarrar, Jalal, 1988), which explored the attitudes of administrators and teachers of regular schools in the Kingdom of Saudi Arabia, towards integration of disabled children in their schools. The study results indicated that the level of knowledge and education for managers and teachers, including the increase in their knowledge in the field of special education, greatly affects their acceptance 
and support for the idea of integration. It is noted that most of the trends and opinions have tended toward integrating mild disabilities in regular schools with finding other alternatives for people with the most severe disabilities.

In a study by (Abdul-Jabbar and Massoud, 2001), which aimed to explore the views of 447 principals and teachers in regular schools that apply the integration in the city of Riyadh, about the integration of the disabled in ordinary schools, and how those views are affected by the variables of function, qualification degree, class of disability and the type of program. The results indicate a positive impact for the application of the integration on the views of the managers and the teachers and accepting it. These opinions are affected by the variables that are associated with the post the qualification degree and the type of disability, or even the program in which the children have enrolled.

The study which is conducted by (Assartawi, 1995) to identify the attitudes of the teachers and the students of the university to integrate children with disabilities in regular classes, which included a sample of teachers from the Ministry of Education and students of the Faculty of Education, in King Saud University in Riyadh, contained 627 teachers and students. The study revealed that these trends tend, in general, to the opposition of the integration from students and teachers while you find an understanding and acceptance from the specialists in special education. The study also noted the support of the study sample for integrating people with mild disabilities and opposition to integrating people with severe disabilities. This study and other studies indicate that the presence of a disabled relative for the individual, is an effective factor to accept the integration, while years of experience in teaching ordinary students, formed a reverse factor in accepting the integration.

In a study conducted by Mohammed Abdul Ghafoor (1999) to identify the variables that contribute to the strengthening of the trend towards the policy of integrating students with special needs in regular classrooms, and that from the point of view of teachers and administrators in public education, clarified that the integration creates opportunities for positive interaction with the ordinary people within the school and the most important educational needs of the integration were: -

1- To determine the disabilities that are accessible for integration.

2- Providing appropriate medical services for the handicapped and the curriculum and its flexibility, and the prepared teacher to deal with the disabled child, and the special educational means for disabled persons.

Therefore, the implementation of integration programs need to focus on four aspects:

1) The preparation of the teaching staff, and selecting the appropriate.

2) Putting the children in appropriate grades and this includes: registering those with disabilities, and selecting the non-disabled for them, or vice versa.

3) Planning and implementation the appropriate strategies: educational assessment, individual educational program, rules of the class discipline, the environment, planning in the classroom, plan and tables, play, strategies inside and outside the classroom.

4) Partnerships between parents and staff.

It is clear, from studies that focused on the trends of those who are working in the environment of integration, the importance of those aspects as a key element in creating and facilitating the task of integration, and thus increasing the opportunities for students with disabilities to take advantage of available services. And it is noticed that all the studies agreed that the teacher plays an important and critical role in the integration, as the responsibility of the success of existing social relations among children in the classroom environment is located primarily on his shoulder As Malmskog and McDonnell (1999) explained in their study, which was implemented in a number of kindergartens in the United States, the crucial role the teacher plays in preparing the classroom environment that stimulates social interaction between ordinary and non-ordinary peers, where intervention appropriate methods increase the level of social interaction for numerous children who do not tend to interact with others.

And in light of the above displayed results of the studies which focused on integration and its associated issues, it is clear that integration includes many of the tasks roles and steps, which educators must take care of and prepare in advance and make sure of their application during the implementation of the integration, as addressing those matters makes the task of those who are working in the integration programs easier and more organized.

\section{Theoretical Framework}

Persons with disabilities have the right to take their chance in the field of education, and putting educational and training programs must be developed according to the type of disability and its degree. Therefore, children with disabilities are entitled to educational opportunities available to all other children in their homeland and society. As education is for all persons with disabilities according to Disabilities Act of 1975 (Mitchill, p396, 1990) And the 
initiative of the collective school, or collective education of the Conference of Salamanca, Spain, in 1994, which stipulates that each child with a disability has a fundamental right to education and must be given this right to attain an acceptable level of education and preserving it, since every child has unique characteristics, interests, abilities and his special needs in education.

The project of The Arab Contract for persons with disabilities (2003-2012) aims in its parts to "work so that a disabled child gets all the rights and services equally with his peers of the children and remove all obstacles that prevent the implementation of that", and in the field of education, the contract aims to "guarantee equal opportunities of education and teaching for all people with disabilities from early childhood in all educational and pedagogical institutions in its general classes.

The terms of the law of the rights of people with disabilities in Jordan number (31) for the year 2007, aims to find opportunities of General, vocational and higher education for people with disabilities according to the categories of disability and through the method of integration, and the adoption of integration programs between students with disabilities and their peers from the non-disabled, and implementing them in the framework of educational institutions. And providing free reasonable accommodation that help persons with disabilities in learning, communication, training and movement., including Braille and sign language for the deaf and other necessary equipment (Official Gazette, 2007).

Children with disabilities must receive education within ordinary education institutions that take this collective approach. And it is the most successful way to all the attitudes of discrimination and isolation, and to find a less restrictive educational communities. And the establishment of a tolerant society and to achieve the goal of education for all. It requires, for some people with disabilities, implementing a substantial modification in the educational program, and the establishment of some of the necessary supporting services. Everyone is responsible for the modification of his educational appliances to provide Inclusive education for people with disabilities as other children without disabilities. However, we believe this contradicts the fact, even if this makes it easier for them to have the right to education, but it goes back and imposes some privacies in this area, and puts them in special schools of their own and cut them off from it (Indian, 1998, p1). I have used many terms to refer to the concept of integration, from these terms, deinstitutionalization, normalization, integration and mainstreaming. All of these concepts refer to the process, which includes distancing the disabled from the special interior boarding and placing them in an open environment which is less restrictive for their freedom as much as possible.

The presence of children in regular school (the least restrictive environment) does not mean the inevitability of their placement in the regular classes, and educational alternatives may vary within the school according to the child's need and the level of services required by his disability and the extent of its availability in regular classrooms.

The results of the study conducted by (Cavllaro et al, 1998) in California, had confirmed that the educational alternatives for integrated children varied by the type of disability and the child's age. Some children get the opportunity to enroll in regular classes throughout the school day, while other children join for short periods, and many children may not be able, especially those with severe disabilities, to attend regular classes at all. The issue of integration of disabled children in public schools has raised great interest in the educational and scientific circles and the debate around it increased between its supporters and those who opposed it. Proponents of the idea, drew their advocacy from the grounds that the right of every individual, regardless of his circumstances, is to live in his natural environment, and that what the institutions do to accommodate the environment and the living conditions for the disabled is but isolating him from the real community in which he is supposed to live with all its advantages and disadvantages. And even it puts them in a narrow framework that they can not come out or surpass it, and this creates a real difficulty, when they find themselves obliged to deal with their natural environment and thus the society and people. And the study of (Freeman \& Alkin, 2000) is consistent in regard to the impact of integration on the performance of integrated children, where this study indicated the effectiveness of the learning environment in improving the level of academic achievement and social behavior of integrated children, compared with those enrolled in schools for special education in the United States. The results of this study showed the importance of using teaching methods and tools that are appropriate for people with disabilities, such as the use of individual educational plans to be employed as curriculum for some children, so as to increase the effectiveness of learning in the environment of integration. When the disabled child participates in integration classes, when he is welcomed and finds acceptance from others, this gives him a sense of self-confidence, and he accepts his disability, and feels belonging to other members of the community in which he lives (Lynch, et al 1999:81).

The disabled child, in the integration classes, acquires new skills and a number of educational opportunities and social models, which helps a more appropriate social growth, and participation in the tasks and leisure activities (Bradley, et al 2000.31). 
The integration also leads to the change in the attitudes of the normal child to get used to the disabled child and to accept him and to feel comfortable with people who are different from him. And many studies revealed the positivism of ordinary children when they find the chance to play with children with disabilities constantly. And in the system integration there is a chance to make friends among different people, and no doubt there are benefits of the integration for the parents as they feel that the disabled child is not isolated from Community They also learn new ways to teach the child. When the parents see the child's remarkable progress and his significant interaction with normal children, they begin to think about the child more, and in a realistic manner. When they see that many of his actions are like those of all children in his age, their feelings towards their child improve, as well as their feelings toward themselves (Lynch, et al from 1999.19-20).

Oponents argue that the application of the idea of integration will expose the disabled to dangers and problems. And that the institutions, save them from exposure to them, and that the programs and services provided by the institutions would not have been obtained in the natural community, and it provide them with the programs and methods, that are commensurate with their abilities and conditions of their disability. In addition to the negative trends which are formed originally in the community about disability and the disabled which need long period of time to get rid of them.

\section{Conditions That Must Be Taken into Account in Planning Programs of Ideal Integration}

The integration is considered a complex operation that requires intact planning to ensure the success of the program and to be planned carefully. As the disabled students, who will benefit from this program, must receive a level of education that is not less than, at least, the applied program in private schools Also the presence of the disabled child in regular schools should not affect, in any way, its program and the level of the progress and ambitions of the students. And not to constitute an additional burden on the teacher in a regular school. Al-Moosa had affirmed (1993) the importance of providing all human and material supplies in regular schools before embarking on the integration program. The views of many specialists and workers in the field of special education indicate the importance of overcoming all the obstacles before and during the integration, through the creation of an integrated team involving all relevant parties and in which everyone bears responsibility for the disabled child. The first requirement for integration is to identify the special educational needs of pupils in general, and in particular those with disabilities, so that to prepare the appropriate educational programs to address them in terms of academic, social and psychological sides in regular classes.

Every disabled child has his own mental abilities, physical capabilities and psychological, social and individual needs which may differ significantly from other disabled persons. (abd - al azez Al-Shakhs: 1987.206).

Abdul Aziz Al-Shakhs (1986) affirms in his study, the need for good preparation for the integration process and preparing the school, training the teachers and the specialists, and developing the curriculum with the need to amend the trends of those who are responsible for the care and rehabilitation of these children. To change the attitudes of all of who are related to the educational process; supervisors, managers and teachers, and prepare them to understand the purpose of the integration, and how the school achieves its goals in the education of disabled persons so that they can contribute positively to the success of their integration in education and preparing them for integration into the community

Prior to the execution of any integration program, it is necessary to provide a group of teachers with expertise in teaching students with special needs, and to prepare them appropriately to deal with the ordinary and the disabled students, and to know how to make the necessary adjustments in teaching methods to meet the needs of persons with disabilities in regular class. Along with knowing the methods of directing and guiding ordinary students to allow them to accept their peers with disabilities.

Among the requirements of integration the importance of preparing the educational curricula and the appropriate educational programs which allow disabled persons to access education, and developing personal, social, and educational skills, and daily living skills to the utmost extent that is qualified by their potential and abilities, and to allow them education and social harmony within the school or outside it. These programs and educational activities should also allow opportunities for students with disabilities to interact with their peers from ordinary students in a way that leads to accepting each other (Abdel Aziz, Al Shakhs: 1987.207)

The importance of preparing the parents of ordinary students, and explaining the dimensions of the experience to them, and its humanitarian, educational, psychological and social dimensions (Magda Obeid: 2000.208-209)

Assartawi (1987) says it is necessary not to rush to apply the integration without prior planning, and he emphasizes the importance of the unity of the formal and informal efforts, and to provide the basic requirements of physical and human resources upon which the integration is built. With the provision of prior awareness and forming the positive 
trends in the society in general and the school staff in particular. And the researcher, in his study, affirms the need for meaningful collaboration among teachers of special education and general education for the success of the integration

The implementation of integration policy requires the existence of certain conditions and abilities with the presence of supportive and consolidating services, in order to provide the best conditions for the success of this policy. The program of integration of disabled students with their peers without disabilities is related to many variables of a different nature. It is linked to the preparation and training for both non-disabled students and students with disabilities (Guralunick, 1999). And it is also strongly linked to the trends of the parents of ordinary children and teachers attitudes and trends of the large community toward those with special needs and to the preparation of teachers, the educational system, the evaluation methods, examinations and the flexibility of these systems, and with the natural environment in which the child learns.

Farouk Sadiq (1998) believes that the process of integration of the child needs planning and preparation of the school, the class, the teacher and the specialists who work with the child for his education, preparation and his guidance and the guidance of his family. And the program must be achieving a partnership between all the elements of the educational or rehabilitative process and that the planning and implementation extend to the local environment, where the child comes from and returns to it after completing the program.

We can say that the success of the integration program is linked to the extent of faith of the educational authority in the philosophy of integration. This authority that has the power to constitute a positive impetus to achieve integration in one way or another, or one degree or another At the same time have the power to form a tremendous impetus to prove that the integration is a successful project. The results of relevant global researches agree that the attitudes of teachers towards integration and their acceptance of it, are among the most important elements that determine the success or failure of this process. But the attitudes of ordinary pupils may be an extension of the trends of their teachers towards them. (Al-Shakhs. 1990:79). The success of the process of integrating people with disabilities, in public schools, depends on a number of factors associated with the teachers and including their acceptance of the idea of integration. Also, the provision of training programs for them during the service to enable them to adapt their teaching methods. And to work in the spirit of the team, and to absorb and understand the individual differences. And to provide teaching materials and the necessary equipment for the teachers with access to information about persons with disabilities and their characteristics and needs, and enjoyment of the necessary support. From the above mentioned, it is clear that integration, in spite of its advantages, is not an easy or simple thing to do. And that when the school desires to do such a step, it should be prepared carefully because it is a sensitive process that affects individuals and parties that live in one community. And each party or group has a specific meaning for integration starting with the disabled child his family and through the employees at the school and its students and ending with the great community. The drawbacks that are viewed make us stop, and not be taken by enthusiasm in the application of the integration. This does not mean the total rejection of integration, but to look at these disadvantages which are, in spite of their difficulty, they are not the difficulties that cannot be solved. Minimizing these drawbacks and comparing them with the advantages and the benefits that will return to the society, such as the development and the recognition of humanity of the disabled persons, will lead to a more objective consideration of the integration.

Therefore, the integration environment must be prepared properly and adequately so as to contribute its part in the desired improvement in the integrated students. This may require the prior preparation and planning for all elements involved in the integration program, where multiple parties cooperate to implement the program, and some modifications may also be involved in the details and features of the educational environment in order not to become an obstacle for the events of the required progress

The success of the disabled students in public education requires a joint cooperation between all the relevant parties of teachers, administrators, normal peers, specialists and the families of these children, in order to facilitate the provision of real integration and appropriate educational experiences for these children (Tapasak, Renee \& Walther Thomas, 1999)

It becomes necessary to make appropriate and necessary changes in the Objectives, concepts and applied policies of education in all countries in the world, so that the scattered parties unite, and children are not separated in different schools under the pretext of individual differences. If the disadvantage of regular schools is the inability to deal with those differences, it is an explicit recognition of the vulnerability of the designed programs to prepare teachers and educational programs that will fit all children.

The solution to this problem will not be in distancing the disabled students and excluding them from public education claiming the impossibility of their success. By such step we deny them their right to participate in the 
normal life. If the regular school, in its present form, is unable to accommodate those students and provide them with the minimum chances of success and sharing, thus it recognizes the existence of a fundamental problem in its massage. This requires that planners and educators must stand seriously with themselves and raise many questions about how to develop and update a regular school in line with the needs of all students with disabilities and without disabilities, not to exclude many of them under the pretext of lack of adequate services.

\section{The Problem of the Study and Its Questions}

The integration of disabled children with non-disabled children is not an easy process, but it's a multi-dimensional process and it is surrounded by risks, which emphasizes the importance of knowing the elements of the continuity of success, as the integration program requires many of the basic components, which are necessary to implement or, to be more precisely, several requirements to ensure the success of the integration of disabled students in regular schools (both in classes attached in the first step, or social integration in the final desired stage,) and we should not forget the fact that the integration has rules and scientific and educational conditions which must be available before and during and after its application. Despite the presence of opponents, the principle of integration has become an urgent educational issue in the field of special education. And perhaps, the most feared by the opponents of the principle of integration is to deprive the disabled of the facilities and services, and special care, whether educational, psychological, social or other assistance. But in order to ensure service providers for people with disabilities about the success of the integration, and accepting it on the educational level or at the level of decision-makers, careful planning for a group of programs that create or prepare for the integration program And we can call it the "pre-integration programs". This emphasizes the importance of knowing the requirements of a successful integration program to ensure access to the hoped benefits of these programs, and to get some recommendations that contribute to providing better opportunities for the success of the style of the integration.

The deficiencies in the information related to integration programs may impede the possibility of generalizing and activating the successful experiences. And thus depriving other schools, who are planning the integration, from the previous distinctive experiences, which may act as incentives for subsequent experiments.

And since there are previous studies, but did not provide detailed information on all the integration programs in the Hashemite Kingdom of Jordan, the importance of this study was to function as a reference for many students and those who are interested in this topic.

To identify the requirements for the success of the integration program, and to find out the reasons for success, and to provide optimal service to students with disabilities in regular schools, the current study attempted to answer the following questions:

1- What are the most important requirements of the success of the integration of disabled persons in regular schools from the viewpoint of the teachers of the learning resources rooms

2- Are there any statistically significant differences to the level of $(\alpha(0.05 \geq$ in the requirements of disabilities program success of integration in regular schools from the teachers of learning resources rooms- perspectives attributed to the variable of gender?

3- Are there any statistically significant differences to the level of $(\alpha(0.05 \geq$ in the requirements of disabilities program success of integration in regular schools from the teachers of learning resources rooms- perspectives attributed to the variable the years of experience?

4- What is the most appropriate educational option for students with disabilities (The academic integration, social integration, classes attached to the regular school, general education class with their peers, the integration program of the full-day, partial day program integration, from the viewpoint of the teachers of the learning resources rooms)?

\section{Definition of Terms}

Definition of: Kaufman, Gottlieb, Agard \& Kukic (1975) which is considered _ in spite of its antiquity one of the most comprehensive and common definitions of integration. They believe that the intended integration "is the integration of non-ordinary qualified children with their peers, educationally, and socially, and temporally and according to a plan, program and a continuous method of education which is determined by the need for each child separately, and on the condition of the clarity of responsibility in the administrative, the educational and the artistic system in the general education and the special education." (Al-Moosa, 1992, Al-Khatib 2004) Kenneth A. (2002, p202)

Procedural definition of integration: integration intended to place students with disabilities in regular schools with students without disabilities within the regular class or in special classes attached to some time or full-time according to the child's need. With the provision of support services through a multi-specializations team and 
making the necessary material and human adjustments to facilitate their chances of success and progress.

Disabled person: each person with total or partial failure in a stable manner in any of the senses, or his physical mental or psychological abilities, to the extent, which limits the possibility of his learning, training or work so that he cannot meet the requirements of normal life in the conditions of the likes of non- disabled. (the law of the rights of people with disabilities, the Official Gazette, 2007)

Regular schools: public schools of general and private education for both sexes which implement programs that integrate children with disabilities.

\section{Method and Procedures}

\subsection{Community and the Study Sample}

The study population included all teachers in resources rooms in the basic public and private schools of the directorates of education in the province of Amman which implement the programs of the integration of students with disabilities. Teachers of resource rooms were selected in the manner of simple random sample, and the sample of the study consists of (40) male and female teachers (20 males and 20 females) from teachers who are working in resource rooms.

\subsection{Procedures of the Study}

1- Preparing the list of the requirements of integration (prepared by the researcher, which consisted of (70) requirements for the integration and partitioned into seven domains to measure two dimensions of the list, these are: requirements for the success of the integration and the type of program is the most important from the perspective of workers.

2- The form was presented to ten arbitrators in the Department of Special Education in Jordanian Universities

3- After the restoration of the arbitrated Forms, the researcher made the adjustments that were proposed by the arbitrators and prepared the form in its final shape.

4- The researcher himself delivered copies to schools that apply the integration.

5- The researcher implemented the unloading operations of the information and extracted the results of the current study using the means and standard deviations.

\subsection{Study Instrument}

In this study, the researcher used a form which he prepared for the collection of information, and it included direct questions and primary data aimed at gathering the information of the requirements for the success of the integration in Jordan. The researcher displayed the Form on 10 arbitrators from the Department of Special Education in the Jordanian Universities to make sure the veracity of the data and the questions that it contained to achieve what its aims. After receiving the list of requirements, and making the adjustments that are proposed by the arbitrators of the integration, the final number was 70 items distributed into seven themes (teachers and administration, school environment, support services, awareness, students with disabilities, the type of the program) to answer the questions of the study.

\subsection{The Validity of the Instrument}

The validity of the instrument was verified through the validity of the content and offering it to (10) members of the staff at the Faculty of Educational Sciences of specialists in the field of special education and guidance to judge the appropriateness and clarity of the items and their affiliation to the domain in which they exist.

\subsection{The Reliability of the Tool}

To verify the reliability of the study instrument the method re-test has been used on an exploratory sample consisting of (25) teacher in the schools that apply the integration program outside the study sample, And re-application with a time lag of two weeks. Pearson correlation coefficient have been calculated between the results of the two applications, and the correlation coefficient was (85.0) for the whole instrument and this reliability coefficient is acceptable for the purposes of this study.

\subsection{Design and Statistical Analysis}

This is a survey descriptive study, which focused on identifying the requirements of the success of the integration program of students with disabilities in regular schools from the perspective of workers, and means and standard deviations were used in the analysis of the collected data. 


\section{Results and Discussion}

\subsection{The First Question}

(What are most important requirements for the success of the integration program of the persons with disabilities in regular schools from the viewpoint of teachers of learning resources rooms)?

To answer this question, means and standard deviations of the estimates of the sample on the areas of study were calculated as in Table 1 and in the total instrument as in the tables (2-7)

The results contained in Table 1 indicate that all the fields of study have high means ranged between $(4,000044,6929)$, where the field of awareness came first, with an a mean of $(4,6929)$ and standard deviation $(0,4299)$, followed by a second domain of support services with a mean of $(4,5500)$ and standard deviation $(0,4512)$, and in the third rank the domain of integration programs with in the a mean of $(4,2722)$ and in the fourth rank the domain the school environment with a mean of $(4,1589)$, and in penultimate rank the teachers with a mean of $(4,0063)$, and in the ultimate rank the domain of students with disabilities with a mean of $(4,0000)$ and standard deviation $(0,3917)$.

It can be interpret that those results are due to the faith of the teachers of learning resources rooms who are working in the field of learning disabilities in the importance of awareness which is addressed to managers, teachers, parents and students without disabilities and students with disabilities themselves .And whenever there is a greater understanding of the needs and desires of the foregoing categories, their attitudes become positive and have a positive impact in facilitating the mechanism of integration. And this is consistent with the results of (Abdel-Aziz person: 1987.206) (guralunick.1999) study which emphasizes the need for good preparation for the integration, and the creation of the school and the training of teachers and specialists with the development of curricula and the need to modify the trends of those involved in the care and rehabilitation of these children. The attitudes of all who are related to the educational process must be changed for the success of the mechanism of integration. The process of educating the community and increasing its awareness about the disabled group and the requirements of their integration in society, as one of the missions that working institutions in this area, seek to achieve. They made great progress in this direction, and this study comes in the context of community awareness of the importance of the integration of this category and the requirements that must be achieved before the integration as well as what requirements are required by the integration.

To know the most the important item as a requirement for the integration mechanism within each area, means and standard deviations were calculated for each area separately.

\subsubsection{The First Domain: Teachers and School Administration}

Table 2 shows means and standard deviations of the items of the domain of teachers and school management in the instrument of the study with the rank of each item. The results indicate that the item of establishing a positive relationship and permanent contact with the parents of students with disabilities in the light of the instructional and educational programs that are open to them. This item in the first rank, with a mean of (4.65) and standard deviation (0.48) followed by item 10 the need for effective coordination with the school administration to overcome the obstacles that hinder the progress of the disabled student, with a mean of (4.45) and standard deviation (0.68), and in the last rank the item 2, Positive attitudes of teachers to do the experience of integration with a mean of (3.20) and standard deviation $(0.75)$

\subsubsection{The Second Domain: The School Environment}

Table 3 shows means and standard deviations of the items of the school environment in the area of study instrument and the rank of each item. The results indicate that the item of The intact selection of appropriate school. With a mean of (4.60) and standard deviation (0.49) and it was in the first rank, followed by the second item of class size which is suitable for the freedom of movement and practicing any activity inside it, with a mean of (4.42) and standard deviation (0.50), and the last rank was the item of the nearness of the school to the residence of students with disabilities. With a mean of (3.75) and standard deviation (0.80)

\subsubsection{The Third Domain: Support Services}

Table 4 shows means and standard deviations of the items of the domain of support services in the instrument of the study and the rank of each item. The results indicate that item to provide health services (functional physiotherapy) was in the first rank, with a mean of (4.77) and Standard deviation (0.42), followed by the second item provision of safe means of transportation to and from school) with a mean of (4.77) and standard deviation (0.42), and the last rank the item of the provision of educational and supporting services for the success of the integration program with a mean of (4.30) and standard deviation (0.79) 


\subsubsection{The Fourth Domain: Awareness}

Table 5 shows means and standard deviations of the items of the domain of awareness in the instrument of the study and the rank of each item, where the results indicate that the item of The need to prepare the parents of ordinary pupils, and to explain the dimensions of the experience to them, and its humanitarian, educational, psychological and social dimensions to them, in the first rank with a mean of (4.77) and standard deviation (0.42), followed by the second item. To modify the trends of the family to be positive, and to accept their disabled child with a mean of (4.75) and standard deviation (4.75), and the last rank was the item of The need to prepare ordinary students, and to create an atmosphere of acceptance and willingness to cooperate for the achievement of the objectives of the program, with a mean of(4.62) and standard deviation (0.54).

\subsubsection{The Fifth Domain: Students with Disabilities}

Table 6 shows means and standard deviations of the items of the domain of students with disabilities in the instrument of the study and the rank of each item, where the results indicate that the item of. Intact and appropriate selection to the group of children intended to be integrated to make sure that they benefit well from the objectives of the program in the first rank, with a mean of(4.42) and standard deviation (0.54), followed by the second item Disabled children should not suffer from serious do difficulties in communicating with a mean of (4.25) and standard deviation (0.54), and the last rank was the item of Age of the disabled child should be of the same age of the ordinary group of students, with a mean of (3.43) and standard deviation (1.31)

\subsubsection{The sixth Domain: The Integration Program}

(1) Table 7 shows the means and standard deviations of the items of the domain of the integration program in the instrument of the study and the rank of each item, the results showed that the item to provide sources of support and management of procedural matter. is in the first rank with a mean of (4.47) and standard deviation (0.50), followed by the second item The provision of educational and supporting services for the success of the integration program with a mean of (4.40) and standard deviation (4.40), and the last rank was the item Application of the integration in a gradual way, that is well-considered previously, with a mean of (4.05) and standard deviation (0.78)

Are there significant differences at the level of $(0.05 \geq \alpha)$ in the requirements of the success of the integration of persons with disabilities in regular schools from the viewpoint of the teachers of learning resource rooms due to gender?

To answer this question, means and standard deviations were calculated for the total degree of the scale and grades sub-grades of its dimensions, according to the variable of gender as it is in Table 1, test (t)was also used to judge the significance of the differences between male and female teachers

(2) It is clear in Table 8 that there is no statistically significant differences between males and females in the following dimensions: -

1- Teachers and school administration, where the value of ( $\mathrm{t})(-1.426)$, which is statistically insignificant at the level of $(0.05 \geq \alpha)$

2 - The school environment, where the value (t) (-1.515), which is statistically insignificant at the level of $(0.05 \geq \alpha)$

3 - support services where the value of T (-1.515), which is statistically insignificant at the level of $(0.05 \geq \alpha)$

4 - awareness of where the value of (t) (0.769), which is statistically insignificant at the level of $(0.05 \geq \alpha)$

5 - students with disabilities, where the value of $\mathrm{T}(-0.819)$, which is statistically insignificant at the level of $(0.05 \geq \alpha)$

As shown in Table (1) there is no statistically significant differences between males and females in the total score on the scale, where the value of $\mathrm{T}(-1.635)$, which is statistically insignificant at the level of $(0.05 \geq \alpha)$.

As shown in Table (1) the existence of statistically significant differences between males and females in the post-integration program, where the value of $(t)(-2.819)$ is statistically insignificant at the level of $(0.05 \geq \alpha)$, were these differences in favor of females where their estimate of the importance of the integration program is higher than the males, the mean for females is (4.3800), while the mean for males is (4.0841)

To find out whether there were statistically significant differences at the level of $(0.05 \geq \alpha)$ in the total score of the scale and sub-grades for his dimensions due to gender, one way ANOVA was used and Table 2 shows that

(3) It is s clear in Table 9 above that there was no statistically significant differences at the level of $(0.05 \geq \alpha)$ in the total degree of the scale and the sub -grades due to gender as the value (P 2.202), which is statistically insignificant, while differences were on the sixth dimension (the integration) between males and females, and that for females, where the mean was 3.043. The absence of statistically significant differences in most dimensions may be because 
both sexes have been qualified at the same university and received the same subjects, without distinction between them.

- Are there significant differences at the level of $(0.05 \geq \alpha)$ in the requirements of the success of the integration program of persons with disabilities in regular schools from the viewpoint of the teacher of resource rooms of learning due to years of experience?.

To answer the question were means and standard deviations of the total degree of the scale and the sub-grades for its dimensions were calculated according to the variable of years of experience as in Table 3.

(4) Table 10 shows that there are clear differences between the means of the estimates of male and female teachers for the importance of the requirements of success, according to the variable of experience in the total score of the scale and the sub-grades of its dimensions due to years of experience. And to determine if there were statistically significant differences at the level of $(0.05 \geq \alpha)$ in the total degree of the scale and the sub-grades of its dimensions due to years of experience, one-way ANOVA has been used, and Table 11 shows that.

(5) Table 11shows that there are statistically significant differences at the level of $(0.05 \geq \alpha)$ in the estimates of the teachers for the requirements for success in the total degree of the scale where the value of $\mathrm{P}$ (14.995), and it is statistically significant at the level of $(0.05 \geq \alpha)$. Table 4 also indicates the existence of statistically significant differences at the level of $(0.05 \geq \alpha)$ in all dimensions that constitute it due to years of experience, namely:

- Teachers and school administration, where the value of P (7.084), and it is statistically significant at the level of $(0.05 \geq \alpha)$

- The school environment. Where the value of $\mathrm{P}(6.985)$, and it is statistically significant at the level of $(0.05 \geq \alpha)$

- Support services. Where the value of $\mathrm{P}(15.820)$, and it is statistically significant at the level of $(0.05 \geq \alpha)$

- Awareness. Where the value of $\mathrm{P}$ (12.073), and it is statistically significant at the level of $(0.05 \geq \alpha)$

- Students with disabilities. Where the value of $\mathrm{P}(8.249)$, and it is statistically significant at the level of $(0.05 \geq \alpha)$

-The integration program, the value of $\mathrm{P}(6.290)$, and it statistically significant at the level of $(0.05 \geq \alpha)$.

To find out between which levels of the variable of experience these differences are found, (Shiva) test of posteriori comparisons was administered, and Table 12 displays these results

Post Hoc Tests.

(6) Table 12 shows that the assessment of teachers whose experience ranges between (6-10) years for the requirements of the success of the integration were higher than the estimates of the teachers whose experience is less than five years in the total degree of the scale and the sub- dimensions that make up the scale except in the dimension of teachers and school administration.

The estimates of teachers who have experience ranging between (6-10) years for the success of the integration requirements were higher than estimates for teachers who are 10 years of experience in the total degree of the scale and its dimensions. It may be because the teachers may have the necessary expertise to deal with students and classroom management, and they are excited to work with the students, and they are ready for tender other than the teachers whose experience is more than 10 years, who may have their own self- burning and therefore do not have the required readiness to accept this category of students inside the ordinary class. The results of this study are consistent with the results of a study by (Assartawi, 1995) which indicated that years of experience in teaching ordinary students work as a reverse factor for accepting the integration.

As the table shows, the estimates of teachers whose experience is less than five years for the importance of teachers and school administration was higher than the estimate of teachers whose experience is over 10 years.

\subsection{Second Question}

(What's the most appropriate educational option for students with disabilities (academic integration, social integration, classes attached to the regular school, general education class with their peers, full-day integration program, partial-day integration program from the viewpoint of teachers of learning resources rooms?)

To answer this question, means and standard deviations for the estimates of the members of the sample on the integration programs according to their importance were calculated as shown in Table 13.

Table 13 shows means and standard deviations for the type of the program, where the results indicate that the program of social integration was in the first rank, with a mean of (4.62) and standard deviation (0.83), followed by the second program, the academic integration program with a mean of (4.23) and standard deviation (0.53), and in the third rank, the ordinary integrated class with a mean of(4.00), followed by the partial integration program with a 
mean of (2.63), and came in the penultimate rank the program of the special class attached to the regular school with a mean of (2.52) and came in the final rank the program of the long- term integration, the (Full-day) with a mean of(2.25) and standard deviation (1.39). This result is expected to be consistent with the estimates of those who are working on the social integration, and this can be explained by the fact that the integration means the social and educational integration of students with disabilities and normal children in regular classrooms and for part of the school day at least. This definition is linked to two conditions which they must be the available, these are: the presence of the student in the normal class for part of the school day in addition to the integral social mixing, which requires integration and continuous educational planning. The concept of integration, in its essence social and moral concept stems from the movement of human rights against the classification and segregation of any person because of his disability as well as the increasing societal attitudes towards the rejection of social stigma for people with disabilities. The policy of integration is the educational practice of the general principle that guides the educational services, and it is the normalization toward normality in environments with the least restrictions.

It can also be possible to explain the importance of the consensus of those who are working on the program of social integration, which, means that, children with disabilities attend public classes in the different activities of the school such as tours, sports , art classes, music and other social activities Because it is the simplest types and forms of integration, since the student with a disability does not share his non-disabled peer in the study within the classroom, but integration is limited to the different educational activities such as sports, arts, breaks, time of meals, school groups, trips ,camps and participating in community-based non-academic activities (Shgair, 2002) and other than that.. Undoubtedly, this helps the social acceptance in school, and it is the first step towards social acceptance in society, and to provide opportunities for persons with disabilities to integrate into the various activities and events of society, and to facilitate their mission to be active members and enjoy everything that is available in the community services, and this is the aim of the special education programs and the integration program, which is the most recent of these programs. The philosophy of integration based on the concepts of human rights, equal opportunities and social justice. Scientific research did not provide sufficient evidence to demonstrate that learning disabled students and their development in the normal classroom, is better than in the special class and there is no evidence reassuring that teachers in general education or special education agree to accept the philosophy of school for everyone. (Khatib, 2004)The long-term program (full day) in the last rank, and this can be explained that the presence of the student with disabilities for a long time with non-disabled students increases the size of his responsibilities and undoubtedly, he is unable to keep up, like his peers. The concept of integration faced big misunderstanding and this creates a real confusion, because some felt that it is a call to close classes and schools of special education, and the education of all children with disabilities in regular classrooms. Hence the term of the least restrictive structure appeared and Stevens explained (Stephens, 1982) this issue by saying: that the integration does not mean the education of all children with disabilities in regular classes, but it means the provision of learning opportunities based on equality, through their placement in the structure of education that is the most appropriate and has the ability to meet their needs In many cases this structure is represented by the ordinary classroom, if it is not all the time, it is for some time at least. What so-called pyramid of educational services for which (Alqraiti, 2001) referred, he called the hierarchical graduation of special education programs and the level of its services. Deno, (1970) has shown that the base of this pyramid is the situations that are the most restrictive (schools full board) and its peak are the conditions that are the least restrictive (social integration):

Wang, Anderson, \& Bram (1985) conducted a comparative study between the effectiveness of special classes and classes of the integration, and the results indicated, in all types of disabilities, that the students who were taught in the integration program in the academic and social domain, excelled more than students who were taught in the special classes, and that the students who had been placed in the comprehensive integration programs perform better than those who have been integrated partially.

\section{Recommendations}

In the light of the results that are reached the recommendations of this study can be summarized as follows:

1- Awareness and activating the role of the media through defining the importance of special education and its role, and to concentrate especially on encouraging community awareness of the importance and effectiveness of the method of educational integration method because it is the practical instrument by which the special education programs, in its recent comprehensive concept are implemented.

2-The continuity in expanding the application of social and academic integration in the Kingdom as the most effective educational methods in the provision of special education programs for students with disabilities, this application is in accordance with clear and specific scientific controls.

3- The integration of students with disabilities in different age stages beginning from kindergartens in all educational 
activities, cultural, educational, sports, entertainment and others.

4- Development of the infrastructure, and designing and equipping the classrooms, and the provision of technical and making-up devices and necessary means of support for people with special needs so as to ensure the comprehensive integration to ensure the activation of their participation in all educational activities.

5- Gradual implementation of the integration strategy in the educational system according to the type of disability, with the preparation of the environment surrounding the child to provide opportunities for appropriate adaptation to the deficiency he suffers.

6- to provide an integrated working team in educational institutions to ensure proper and effective application to integrate people with a disability in the educational system, with implementing the necessary training to staff of the schools who apply the experience of the integration.

\section{References}

Al Moosa, A. (1992). The integration of visually impaired children in regular schools: its nature, its programs, and its justification. King Saud University, Saudi Arabia.

Al Moosa, A. (1993). Integration of visually impaired children in regular schools, and its nature, programs and justification. King Saud University, Saudi Arabia.

Assartawi, Z., \& Assartawi, J. (1988). Recognizing the views of teachers and managers in the city of Riyadh on the patterns of the appropriate stereotypes of educational service for persons with disabilities and integrating them. King Saud University, Saudi Arabia.

Alabd eljabbar, A., \& Massoud, W. (2001). Investigation of the views of managers and teachers in regular school about programs of integration. King Saud University, Saudi Arabia.

Alqraiti, M. (2001). Psychology of those with special needs and their education. Dar Al-Fikr Arab, Cairo, Egypt.

Cook, M., \& Gerrer, M. (1991).Attitudes of principals and Special Education Teachers Towards the Inclusion of students with Disabilities. Remedial and special Education, 20(4), 199-207. http://dx.doi.org/10.1177/074193259902000403

Freeman, S., \& Alkin, M. (2000). Academic and Social Attainments of children with Mental Retardation in General Education and Special Education Settings. Premedical \& Special Education, 21(1), 3-18. http://dx.doi.org/10.1177/074193250002100102

Khatib, J. (2004). Education of students with special needs in regular school. Dar Wael for publication, Amman, Jordan.

Kenneth, A. (2002).Mainstreaming to full inclusion: from orthogenesis to pathogenesis of an idea .International Journal of Disability, 49(2), 201-213

Malmskog, S., \& Mcdonnell, A. (1999). Teacher mediatedaciltiation of Engagement by children with Developmental Deles in inclusive Pre-schools. Topics in Early Childhood Special Education, 19(4), 203-216. http://dx.doi.org/10.1177/027112149901900401

Obaid, M. (2000). Teaching children of special needs. Dar al-Safa for publication and distribution, Amman.

Sadiq, F. (1998). From integration to the harmony and complete absorption. Symposium of integration of persons with special needs in the GCC countries. Bahrain.

Tapasak, R., \& Walther, C. (1999). Education of a first year Inclusion program. Remedial and Special Education, 20(4), 216-225. http://dx.doi.org/10.1177/074193259902000405

Zakaria, Z. (1995). Schools do not exclude anyone from students. Journal of Studies, University of Jordan, 22 (16), 65-79 
Table 1. Means and standard deviations of the estimates of the sample members on the areas of the study and the overall instrument in descending order

\begin{tabular}{|l|c|c|c|}
\hline Area & Arithmetic average & Standard deviation & \\
\hline Awareness & 4,6929 & 0,4299 & 1 \\
\hline Support Services & 4,5500 & 0,4512 & 2 \\
\hline Integration programs & 4,2722 & 0,6604 & 3 \\
\hline School Environment & 4,1589 & 0,4434 & 4 \\
\hline Teachers and school administration & 4,0063 & 0,3917 & 5 \\
\hline Students with disabilities & 4,0000 & 0,3917 & 6 \\
\hline
\end{tabular}

Table 2. Means and standard deviations of the field of teachers and school management

\begin{tabular}{|c|c|c|c|c|}
\hline No. & Item & Mean & $\begin{array}{l}\text { Standard } \\
\text { deviation }\end{array}$ & Rank \\
\hline 1 & $\begin{array}{l}\text { Teachers' preparations to the experience of integration were } \\
\text { suitable and thev have }\end{array}$ & 3.47 & 0,64 & 15 \\
\hline 2 & Positive attitudes of teachers to do the experience of integration & 3,20 & 0,75 & 16 \\
\hline 3 & $\begin{array}{l}\text { Teachers' qualifications are appropriate and specialized in } \\
\text { special education }\end{array}$ & 3,75 & 1,10 & 11 \\
\hline 4 & $\begin{array}{l}\text { Change teaching strategies with students with disabilities and } \\
\text { focus on the individual teaching. }\end{array}$ & 3,70 & 0,93 & 13 \\
\hline 5 & $\begin{array}{l}\text { Establishing a positive relationship and permanent contact with } \\
\text { parents of students with disabilities in the light of the } \\
\text { educational programs that are open to them. }\end{array}$ & 4,65 & 0,48 & 1 \\
\hline 6 & $\begin{array}{l}\text { Promote positive interaction between students with special } \\
\text { needs and their ordinary colleagues }\end{array}$ & 4,12 & 0,72 & 9 \\
\hline 7 & $\begin{array}{l}\text { Effective coordination and teamwork and the participation of } \\
\text { evervone in the planning and implementation within the school }\end{array}$ & 3,72 & 1,44 & 12 \\
\hline 8 & $\begin{array}{l}\text { Application of curricula using the suitable techniques and } \\
\text { methods for the disabled }\end{array}$ & 4,37 & 0,49 & 3 \\
\hline 9 & $\begin{array}{l}\text { Selection of effective methods in the motivation that are fit for } \\
\text { the case of each disability }\end{array}$ & 4,20 & 0,72 & 7 \\
\hline 10 & $\begin{array}{l}\text { The need for effective coordination with the school } \\
\text { administration to overcome the obstacles that hinder the } \\
\text { progress of the disabled student. }\end{array}$ & 4,45 & 0,68 & 2 \\
\hline 11 & $\begin{array}{l}\text { Give teachers the freedom to make professional decisions in } \\
\text { modifving the curriculum and adding the appropriate programs. }\end{array}$ & 4,22 & 0,73 & 6 \\
\hline 12 & $\begin{array}{l}\text { Giving courses on special education for school staff to identify } \\
\text { the disabled in school }\end{array}$ & 4,27 & 0,67 & 5 \\
\hline 13 & $\begin{array}{l}\text { Flexibility and accepting the students with disabilities by the } \\
\text { normal classroom teacher }\end{array}$ & 3,55 & 1,23 & 14 \\
\hline 14 & $\begin{array}{l}\text { Positive acceptance by the director of the school to the presence } \\
\text { of children with disabilities and his/her interaction with this } \\
\text { group }\end{array}$ & 3,92 & 1,16 & 10 \\
\hline 15 & $\begin{array}{l}\text { Training and educating teachers and a way that suites the } \\
\text { objectives of the program }\end{array}$ & 4,17 & 0,71 & 8 \\
\hline 16 & Teamwork and participation in the planning and implementation & 4,30 & 0,68 & 4 \\
\hline
\end{tabular}


Table 3. Means and standard deviations for the school environment

\begin{tabular}{|c|c|c|c|c|}
\hline No. & Item & Mean & $\begin{array}{l}\text { Standard } \\
\text { deviation }\end{array}$ & Rank \\
\hline 17 & The intact selection of appropriate school & 4.60 & 0.49 & 1 \\
\hline 18 & $\begin{array}{l}\text { Modifying and harmonizing the method of teaching to the } \\
\text { students of integration }\end{array}$ & 3.97 & 0.94 & 11 \\
\hline 19 & $\begin{array}{l}\text { Modifying and harmonizing the content of the subjects' } \\
\text { domains }\end{array}$ & 4.15 & 0.69 & 9 \\
\hline 20 & $\begin{array}{l}\text { Providing support services, equipment, educational activities } \\
\text { and basic technical supports }\end{array}$ & 4.32 & 0.62 & 6 \\
\hline 21 & $\begin{array}{l}\text { The willingness and desire of the school principal to apply } \\
\text { the integration in his school }\end{array}$ & 3.75 & 0.83 & 13 \\
\hline 22 & $\begin{array}{l}\text { The nearness of the school to the residence of students with } \\
\text { disabilities }\end{array}$ & 3.75 & 0.80 & 14 \\
\hline 23 & $\begin{array}{l}\text { Provide a curriculum with a variety of forms suitable for of } \\
\text { the disability }\end{array}$ & 3.97 & 0.80 & 10 \\
\hline 24 & Provide a suitable school building & 4.35 & 0.62 & 4 \\
\hline 25 & $\begin{array}{l}\text { Cooperation of the council of parents and teachers to } \\
\text { contribute to the success of the experiment }\end{array}$ & 4.32 & 0.47 & 5 \\
\hline 26 & $\begin{array}{l}\text { Class size which is suitable for the freedom of movement } \\
\text { and practicing any activity inside it. }\end{array}$ & 4.42 & 0.50 & 2 \\
\hline 27 & $\begin{array}{l}\text { Provide incentives and advantages to the school where there } \\
\text { is an integration by the Ministry }\end{array}$ & 4.15 & 0.83 & 8 \\
\hline 28 & Positive unconditional acceptance of students & 3.95 & 0.71 & 12 \\
\hline 29 & $\begin{array}{l}\text { The need to prepare the public school students for the } \\
\text { program and to familiarize them with the characteristics of } \\
\text { children intended to be integrated to create positive } \\
\text { atmospheres for acceptance between them }\end{array}$ & 4.15 & 0.76 & 7 \\
\hline 30 & $\begin{array}{l}\text { The provision of specialist teacher to work with the children } \\
\text { with disabilities in the school }\end{array}$ & 4.35 & 0.80 & 3 \\
\hline
\end{tabular}


Table 4. Means and standard deviations for the field of support services

\begin{tabular}{|c|l|c|c|c|}
\hline No. & Items & Means & $\begin{array}{c}\text { Standard } \\
\text { deviations }\end{array}$ & Rank \\
\hline 31 & $\begin{array}{l}\text { The provision of educational and supporting services for } \\
\text { the success of the integration program }\end{array}$ & 4.30 & 0.79 & 7 \\
\hline 32 & Provision of learning resources room & 4.55 & 0.50 & 3 \\
\hline 33 & Provide room and a coach of articulation treatment & 4.52 & 0.55 & 4 \\
\hline 34 & $\begin{array}{l}\text { Provision of psychological and counseling services } \\
\text { (male/ female mentor and a full-time social worker.) }\end{array}$ & 4.50 & 0.64 & 5 \\
\hline 35 & Provision of recreational activities (sports, art) & 4.45 & 055 & 6 \\
\hline 36 & $\begin{array}{l}\text { Provision of safe means of transportation to and from } \\
\text { school) }\end{array}$ & 4.75 & 0.43 & 2 \\
\hline 37 & Provision of health services ( functional physiotherapy ) & 4.77 & 0.42 & 1 \\
\hline
\end{tabular}

Table 5. Means and standard deviations for the field of awareness

\begin{tabular}{|c|l|c|c|c|}
\hline No. & Item & Means & $\begin{array}{c}\text { Standard } \\
\text { deviation }\end{array}$ & Rank \\
\hline 38 & $\begin{array}{l}\text { The need to prepare ordinary students, and to create an } \\
\text { atmosphere of acceptance and willingness to cooperate } \\
\text { for the achievement of the objectives of the program. }\end{array}$ & 4.62 & 0.54 & 7 \\
\hline 39 & $\begin{array}{l}\text { The need to prepare teachers, and to explain the } \\
\text { dimensions of experience for them, and its human, } \\
\text { educational, psychological and social dimensions }\end{array}$ & 4.65 & 0.48 & 6 \\
\hline 40 & $\begin{array}{l}\text { The need to prepare parents of ordinary student, and to } \\
\text { explain the dimensions of the experience to them, and } \\
\text { its humanitarian, educational, psychological and social } \\
\text { dimensions }\end{array}$ & 4.77 & 0.42 & 1 \\
\hline 41 & $\begin{array}{l}\text { Awareness of the features and characteristics of children } \\
\text { with special needs and their problems }\end{array}$ & 4.65 & 0.48 & 5 \\
\hline 42 & $\begin{array}{l}\text { Intensive media awareness at the community level } \\
\text { through the media, the audio, visual and print }\end{array}$ & 4.65 & 0.48 & 4 \\
\hline 43 & $\begin{array}{l}\text { Give courses on special education for school staff to } \\
\text { identify this integrated group in the school }\end{array}$ & 4.75 & 0.44 & 3 \\
\hline 44 & $\begin{array}{l}\text { To modify the trends of the family to be positive, and to } \\
\text { accept their disabled child. }\end{array}$ & 4.75 & 4.75 & 2 \\
\hline
\end{tabular}


Table 6. Means and standard deviations for the domain of students with disabilities

\begin{tabular}{|c|c|c|c|c|}
\hline No. & Paragraph & Means & $\begin{array}{l}\text { Standard } \\
\text { deviation }\end{array}$ & Rank \\
\hline 45 & $\begin{array}{l}\text { Age of the disabled child should be of the same age of the } \\
\text { ordinary group of students }\end{array}$ & 3,43 & 1,31 & 11 \\
\hline 46 & $\begin{array}{l}\text { The child's ability to rely on himself in fulfilling his needs at } \\
\text { school (to master self-care skills) }\end{array}$ & 3.92 & 0.91 & 8 \\
\hline 47 & $\begin{array}{l}\text { The living area of the disabled child from the same region or } \\
\text { the surrounding residential area where the school exists }\end{array}$ & 3.97 & 1.04 & 7 \\
\hline 48 & $\begin{array}{l}\text { Not to use equipment and tools cause chaos or discomfort in } \\
\text { the classroom }\end{array}$ & 4.15 & 0.76 & 4 \\
\hline 49 & Should not have multiple or dual disabilities (Double) & 3.43 & 1.31 & 10 \\
\hline 50 & $\begin{array}{l}\text { Taking into account the child's ability to learn in large } \\
\text { learning groups during viewing teaching materials }\end{array}$ & 4.10 & 0.84 & 5 \\
\hline 51 & The disability of the disabled child is simple or minor & 3.98 & 1.04 & 6 \\
\hline 52 & $\begin{array}{l}\text { Taking into account the ability of the child with disability, and } \\
\text { to keep pace with the school program and to adapt himself to } \\
\text { it. }\end{array}$ & 3.85 & 0.94 & 9 \\
\hline 53 & Positive view of the student with disability for himself. & 4.17 & 0.54 & 3 \\
\hline 54 & $\begin{array}{l}\text { Disabled children should not suffer from serious difficulties in } \\
\text { communicating }\end{array}$ & 4.25 & 0.54 & 2 \\
\hline 55 & $\begin{array}{l}\text { Intact and appropriate selection to the group of children } \\
\text { intended to be integrated to make sure that they benefit well } \\
\text { from the objectives of the program }\end{array}$ & 4.42 & 0.54 & 1 \\
\hline
\end{tabular}

Table 7. Means and standard deviations for the domain of the integration program

\begin{tabular}{|l|l|c|c|c|}
\hline No. & Item & Means & $\begin{array}{c}\text { Standard } \\
\text { deviation }\end{array}$ & Rank \\
\hline 56 & $\begin{array}{l}\text { procedural, accurate and unambiguous definition of the } \\
\text { Integration }\end{array}$ & 4.20 & 0.75 & 7 \\
\hline 57 & $\begin{array}{l}\text { The definition of the target group of the integration program in a } \\
\text { way that helps to determine the criteria for their appropriate } \\
\text { selection }\end{array}$ & 4.17 & 074 & 8 \\
\hline 58 & $\begin{array}{l}\text { To determine the objectives of the program (long-term and } \\
\text { short-term) to be formulated in an objective way that can be } \\
\text { achieved }\end{array}$ & 4.32 & 0.82 & 3 \\
\hline 59 & Determine the criteria and the conditions of the integration & 4.25 & 0.77 & 6 \\
\hline 60 & $\begin{array}{l}\text { Application of the integration in a gradual way, that is } \\
\text { well-considered previously, }\end{array}$ & 4.05 & 0.78 & 9 \\
\hline 61 & $\begin{array}{l}\text { Provision of information, planning and implementation of } \\
\text { training programs }\end{array}$ & 4.32 & 0.79 & 4 \\
\hline 62 & $\begin{array}{l}\text { Provide sources of support and management of procedural } \\
\text { matters }\end{array}$ & 4.47 & 0.50 & 1 \\
\hline 63 & $\begin{array}{l}\text { The provision of educational and supporting services for the } \\
\text { success of the integration program }\end{array}$ & 4.40 & 4.40 & 2 \\
\hline 64 & $\begin{array}{l}\text { The number of students to be integrated into the regular class } \\
\text { should not be more than two students }\end{array}$ & 4.25 & 1.01 & 5 \\
\hline
\end{tabular}


Table 8. Means and standard deviations for the total scale score and its dimensions according to the variable of gender

\begin{tabular}{|c|c|c|c|c|c|c|c|}
\hline \multicolumn{2}{|l|}{ Dimension } & \multirow{2}{*}{$\begin{array}{c}\text { Number } \\
70\end{array}$} & \multirow{2}{*}{$\begin{array}{l}\text { means } \\
3.9696\end{array}$} & \multirow{2}{*}{$\begin{array}{c}\begin{array}{c}\text { Standard } \\
\text { deviations }\end{array} \\
.45116\end{array}$} & \multirow{2}{*}{$\begin{array}{c}\mathrm{T} \\
-1.426 \\
\end{array}$} & \multirow{2}{*}{$\begin{array}{c}\begin{array}{c}\text { Degrees of } \\
\text { freedom }\end{array} \\
138\end{array}$} & \multirow{2}{*}{$\begin{array}{c}\begin{array}{c}\text { Significance } \\
\text { level }\end{array} \\
0.156\end{array}$} \\
\hline Teachers and & male & & & & & & \\
\hline administration & female & 69 & 4.0679 & .36091 & & & \\
\hline & Total & 139 & 4.0184 & .41035 & & & \\
\hline \multirow{3}{*}{$\begin{array}{l}\text { School } \\
\text { Environment }\end{array}$} & male & 70 & 4.0969 & .42442 & -1.515 & 138 & 0.132 \\
\hline & female & 69 & 4.2091 & .43072 & & & \\
\hline & Total & 139 & 4.1526 & .42971 & & & \\
\hline \multirow{3}{*}{$\begin{array}{l}\text { Support } \\
\text { Services }\end{array}$} & male & 70 & 4.5408 & .42259 & -1.515 & 138 & 0.132 \\
\hline & female & 69 & 4.5714 & .44303 & & & \\
\hline & Total & 139 & 4.5560 & .43156 & & & \\
\hline \multirow[t]{3}{*}{ Awareness } & male & 70 & 4.7224 & .40617 & 0.769 & 138 & 0.443 \\
\hline & female & 69 & 4.6749 & .43955 & & & \\
\hline & Total & 139 & 4.6989 & .42221 & & & \\
\hline \multirow{3}{*}{$\begin{array}{l}\text { Students with } \\
\text { disabilities }\end{array}$} & male & 70 & 3.9468 & .59088 & -0.819 & 138 & 0.414 \\
\hline & female & 69 & 4.0474 & .72302 & & & \\
\hline & Total & 139 & 3.9967 & .65933 & & & \\
\hline \multirow{3}{*}{$\begin{array}{l}\text { Integration } \\
\text { Program }\end{array}$} & male & 70 & 4.0841 & .65542 & -2.819 & 138 & 0.006 \\
\hline & female & 69 & 4.3800 & .59268 & & & \\
\hline & Total & 139 & 4.2310 & .64025 & & & \\
\hline \multirow[t]{3}{*}{ Total } & male & 70 & 4.0267 & .34043 & -1.635 & 138 & 0.104 \\
\hline & female & 69 & 4.1141 & .35355 & & & \\
\hline & Total & 139 & 4.0701 & .34851 & & & \\
\hline
\end{tabular}


Table 9. One-way ANOVA for the total degree of the scale and the sub-grades for its dimensions according to the variable of gender.

\begin{tabular}{|c|c|c|c|c|c|c|}
\hline \multicolumn{7}{|l|}{ One-way ANOVA } \\
\hline & & Sum of Squares & df & Mean Square & $\mathrm{F}$ & Sig. \\
\hline \multirow{3}{*}{$\begin{array}{l}\text { Teachers and } \\
\text { school } \\
\text { administration }\end{array}$} & $\begin{array}{l}\text { Between } \\
\text { Groups }\end{array}$ & .336 & 1 & .336 & 2.008 & .159 \\
\hline & $\begin{array}{l}\text { Within } \\
\text { Groups }\end{array}$ & 22.902 & 137 & .167 & & \\
\hline & Total & 23.238 & 138 & & & \\
\hline \multirow[t]{3}{*}{$\begin{array}{l}\text { School } \\
\text { Environment }\end{array}$} & $\begin{array}{l}\text { Between } \\
\text { Groups }\end{array}$ & .437 & 1 & .437 & 2.392 & .124 \\
\hline & $\begin{array}{l}\text { Within } \\
\text { Groups }\end{array}$ & 25.044 & 137 & .183 & & \\
\hline & Total & 25.482 & 138 & & & \\
\hline \multirow[t]{3}{*}{ Support Services } & $\begin{array}{l}\text { Between } \\
\text { Groups }\end{array}$ & .033 & 1 & .033 & .174 & .677 \\
\hline & $\begin{array}{l}\text { Within } \\
\text { Groups }\end{array}$ & 25.669 & 137 & .187 & & \\
\hline & Total & 25.702 & 138 & & & \\
\hline \multirow[t]{3}{*}{ Awareness } & $\begin{array}{l}\text { Between } \\
\text { Groups }\end{array}$ & .078 & 1 & .078 & .438 & .509 \\
\hline & $\begin{array}{l}\text { Within } \\
\text { Groups }\end{array}$ & 24.521 & 137 & .179 & & \\
\hline & Total & 24.600 & 138 & & & \\
\hline \multirow[t]{3}{*}{$\begin{array}{l}\text { Students with } \\
\text { disabilities }\end{array}$} & $\begin{array}{l}\text { Between } \\
\text { Groups }\end{array}$ & .352 & 1 & .352 & .809 & .370 \\
\hline & $\begin{array}{l}\text { Within } \\
\text { Groups }\end{array}$ & 59.638 & 137 & .435 & & \\
\hline & Total & 59.990 & 138 & & & \\
\hline \multirow[t]{3}{*}{$\begin{array}{l}\text { Integration } \\
\text { Program }\end{array}$} & $\begin{array}{l}\text { Between } \\
\text { Groups }\end{array}$ & 3.043 & 1 & 3.043 & 7.787 & .006 \\
\hline & $\begin{array}{l}\text { Within } \\
\text { Groups }\end{array}$ & 53.527 & 137 & .391 & & \\
\hline & Total & 56.569 & 138 & & & \\
\hline \multirow[t]{3}{*}{ Total } & $\begin{array}{l}\text { Between } \\
\text { Groups }\end{array}$ & .265 & 1 & .265 & 2.202 & .140 \\
\hline & $\begin{array}{l}\text { Within } \\
\text { Groups }\end{array}$ & 16.496 & 137 & .120 & & \\
\hline & Total & 16.762 & 138 & & & \\
\hline
\end{tabular}


Table 10. Means and standard deviations of the total degree of the scale and the sub-grades for its dimensions, according to the variable of experience.

\begin{tabular}{|c|c|c|c|c|}
\hline Dimension & Experience & $\mathrm{N}$ & Mean & Std. Deviation \\
\hline \multirow{4}{*}{$\begin{array}{l}\text { Teachers and school } \\
\text { administration }\end{array}$} & lees 5 & 47 & 4.0691 & .43423 \\
\hline & $6-10$ & 47 & 4.1383 & .41477 \\
\hline & more 10 & 46 & 3.8451 & .31533 \\
\hline & Total & 140 & 4.0188 & .40889 \\
\hline \multirow[t]{4}{*}{ School Environment } & lees 5 & 47 & 4.1125 & .26840 \\
\hline & $6-10$ & 47 & 4.3252 & .46358 \\
\hline & more 10 & 46 & 4.0140 & .47011 \\
\hline & Total & 140 & 4.1515 & .42835 \\
\hline \multirow[t]{4}{*}{ Support Services } & lees 5 & 47 & 4.4195 & .40887 \\
\hline & $6-10$ & 47 & 4.8146 & .30219 \\
\hline & more 10 & 46 & 4.4130 & .46093 \\
\hline & Total & 140 & 4.5500 & .43585 \\
\hline \multirow[t]{4}{*}{ Awareness } & lees 5 & 47 & 4.5653 & .45465 \\
\hline & $6-10$ & 47 & 4.9240 & .22261 \\
\hline & more 10 & 46 & 4.5932 & .45671 \\
\hline & Total & 140 & 4.6949 & .42330 \\
\hline \multirow[t]{4}{*}{ Students with disabilities } & lees 5 & 47 & 3.9033 & .46871 \\
\hline & $6-10$ & 47 & 4.2843 & .58229 \\
\hline & more 10 & 46 & 3.7727 & .80374 \\
\hline & Total & 140 & 3.9883 & .66446 \\
\hline \multirow[t]{4}{*}{ Integration Program } & lees 5 & 47 & 4.1111 & .51494 \\
\hline & $6-10$ & 47 & 4.4917 & .63141 \\
\hline & more 10 & 46 & 4.0918 & .68825 \\
\hline & Total & 140 & 4.2325 & .63820 \\
\hline \multirow[t]{4}{*}{ Total } & lees 5 & 47 & 4.0103 & .27699 \\
\hline & $6-10$ & 47 & 4.2684 & .30587 \\
\hline & more 10 & 46 & 3.9217 & .36510 \\
\hline & Total & 140 & 4.0679 & .34826 \\
\hline
\end{tabular}


Table 11. Shows One-way ANOVA for the total degree of the scale and the sub-grades for its dimensions, according to the variable of years of experience.

\begin{tabular}{|c|c|c|c|c|c|c|}
\hline \multicolumn{7}{|l|}{ ANOVA } \\
\hline & & Sum of Squares & $\mathrm{df}$ & Mean Square & $\mathrm{F}$ & Sig. \\
\hline \multirow{3}{*}{$\begin{array}{l}\text { Teachers and } \\
\text { school } \\
\text { administration }\end{array}$} & $\begin{array}{l}\text { Between } \\
\text { Groups }\end{array}$ & 2.178 & 2 & 1.089 & 7.084 & .001 \\
\hline & $\begin{array}{l}\text { Within } \\
\text { Groups }\end{array}$ & 21.062 & 137 & .154 & & \\
\hline & Total & 23.240 & 139 & & & \\
\hline \multirow{3}{*}{$\begin{array}{l}\text { School } \\
\text { Environment }\end{array}$} & $\begin{array}{l}\text { Between } \\
\text { Groups }\end{array}$ & 2.360 & 2 & 1.180 & 6.985 & .001 \\
\hline & $\begin{array}{l}\text { Within } \\
\text { Groups }\end{array}$ & 23.145 & 137 & .169 & & \\
\hline & Total & 25.505 & 139 & & & \\
\hline \multirow{3}{*}{$\begin{array}{l}\text { Support } \\
\text { Services }\end{array}$} & $\begin{array}{l}\text { Between } \\
\text { Groups }\end{array}$ & 4.954 & 2 & 2.477 & 15.820 & .000 \\
\hline & $\begin{array}{l}\text { Within } \\
\text { Groups }\end{array}$ & 21.451 & 137 & .157 & & \\
\hline & Total & 26.405 & 139 & & & \\
\hline \multirow[t]{3}{*}{ Awareness } & $\begin{array}{l}\text { Between } \\
\text { Groups }\end{array}$ & 3.732 & 2 & 1.866 & 12.073 & .000 \\
\hline & $\begin{array}{l}\text { Within } \\
\text { Groups }\end{array}$ & 21.175 & 137 & .155 & & \\
\hline & Total & 24.907 & 139 & & & \\
\hline \multirow[t]{3}{*}{$\begin{array}{l}\text { Students with } \\
\text { disabilities }\end{array}$} & $\begin{array}{l}\text { Between } \\
\text { Groups }\end{array}$ & 6.596 & 2 & 3.298 & 8.249 & .000 \\
\hline & $\begin{array}{l}\text { Within } \\
\text { Groups }\end{array}$ & 54.773 & 137 & .400 & & \\
\hline & Total & 61.369 & 139 & & & \\
\hline \multirow{3}{*}{$\begin{array}{l}\text { Integration } \\
\text { Program }\end{array}$} & $\begin{array}{l}\text { Between } \\
\text { Groups }\end{array}$ & 4.762 & 2 & 2.381 & 6.290 & .002 \\
\hline & $\begin{array}{l}\text { Within } \\
\text { Groups }\end{array}$ & 51.853 & 137 & .378 & & \\
\hline & Total & 56.615 & 139 & & & \\
\hline \multirow[t]{3}{*}{ Total } & $\begin{array}{l}\text { Between } \\
\text { Groups }\end{array}$ & 3.028 & 2 & 1.514 & 14.995 & .000 \\
\hline & $\begin{array}{l}\text { Within } \\
\text { Groups }\end{array}$ & 13.831 & 137 & .101 & & \\
\hline & Total & 16.859 & 139 & & & \\
\hline
\end{tabular}


Table 12. Shows that the assessment of teachers whose experience ranges between (6-10) years for the requirements of the success of the integration were higher than the estimates of the teachers whose experience is less than five years in the total degree of the scale and the sub- dimensions that make up the scale except in the dimension of teachers and school administration.

\begin{tabular}{|c|c|c|c|c|c|}
\hline Dimension & Years of Experience & Average & $\begin{array}{c}\text { Less than } 5 \\
\text { years }\end{array}$ & $6-10$ years & $\begin{array}{l}\text { More than } 10 \\
\text { years }\end{array}$ \\
\hline \multirow[t]{3}{*}{1} & Less than 5 years & 4.069 & - & 0.069 & 0.22 \\
\hline & ( 6-10) years & 4.14 & - & - & 0.29 \\
\hline & More than 10 years & 3.85 & - & - & - \\
\hline \multirow[t]{3}{*}{2} & Less than 5 years & 4.11 & - & 0.212 & 0.098 \\
\hline & ( 6-10) years & 4.32 & - & - & 0.311 \\
\hline & More than 10 years & 4.01 & - & - & - \\
\hline \multirow[t]{3}{*}{3} & Less than 5 years & 4.41 & - & 0.395 & 0.0064 \\
\hline & (6-10) years & 4.81 & - & - & 0.4015 \\
\hline & More than 10 years & 4.41 & - & - & - \\
\hline \multirow[t]{3}{*}{4} & Less than 5 years & 4.56 & - & 0.3586 & 0.5278 \\
\hline & (6-10) years & 4.92 & - & - & 0.3308 \\
\hline & More than 10 years & 4.59 & - & - & - \\
\hline \multirow[t]{3}{*}{5} & Less than 5 years & 3.90 & - & 0.381 & 0.1305 \\
\hline & ( 6-10) years & 4.28 & - & - & 0.5116 \\
\hline & More than 10 years & 3.77 & - & - & - \\
\hline \multirow[t]{3}{*}{6} & Less than 5 years & 4.11 & - & 0.380 & 0.0193 \\
\hline & ( 6-10) years & 4.49 & - & - & 0.3999 \\
\hline & More than 10 years & 4.09 & - & - & - \\
\hline
\end{tabular}

* The mean difference is significant at the 0.05 level.

Table 13. Means and standard deviations for the integration programs according to their importance.

\begin{tabular}{|c|l|c|c|c|}
\hline No. & Item & Means & Standard deviation & Rank \\
\hline 65 & Academic Integration Program & 4,23 & 0,53 & 2 \\
\hline 66 & Social integration program & 4,62 & 0,83 & 1 \\
\hline 67 & Long integration program (full day) & 2,25 & 1,39 & 6 \\
\hline 68 & Partial integration program & 2,63 & 1,35 & 4 \\
\hline 69 & $\begin{array}{l}\text { Program of special class attached to regular } \\
\text { school }\end{array}$ & 2,52 & 1,01 & 5 \\
\hline 70 & $\begin{array}{l}\text { Program of ordinary class attached to it students } \\
\text { with disabilities }\end{array}$ & 4,00 & 1,35 & 3 \\
\hline
\end{tabular}

